\title{
INDONESIAN PROPERTY AND REAL ESTATE RETURN ANALYSIS : COMPARISON OF CAPITAL ASSET PRICING MODEL AND FAMA-FRENCH THREE FACTORS MODEL
}

\author{
M. Bobby Afif Nasution*)1, Hermanto Siregar ${ }^{* *}$, and Trias Andati***) \\ *) School of Business, IPB University \\ Jl. Raya Pajajaran, Bogor 16151 \\ ${ }^{* *}$ Departement of Economics, Faculty of Economics and Management, IPB University \\ Jl. Agatis, Campus IPB Dramaga Bogor 16680 \\ ${ }^{* * *}$ PT Adhimix Precast Indonesia Indonesia \\ JL. Raya Pasar Minggu, No. 17 A, Jakarta Selatan 12780
}

\begin{abstract}
A nation's economic growth can be reflected in property and real estate sector growth. Property and real estate are believed to be one leading sector that is indicating a nation economic health, as this sector grows alongside the national economic growth. Property and real estate are a long term business that requires a large sum of capital. Therefore, many firms in these sectors listed their share in the capital market to attract potential investment form investors. However, property and real estate have risks due to its long term nature, which the investors must avoid. This research aimed (1) to determine two major risks on the property and real estate, economic growth and firms size, and value stocks by using Capital Asset Pricing Model and Fama-French Three Factor Model; (2) and to identify the best model that could detect the best return for property and real estate sector. The result showed that the economic condition was significantly affecting the Indonesia property and real estate sector's excess return. Large size with low bookto-market ratio firms were dominating the property and real estate sector. In conclusion, both models showed similar and consistent results; however the Fama-French ThreeFactor Model was better in identifying excess return of Indonesian property and real estate sectors.
\end{abstract}

Keywords: CAPM, property and real estate, three factor model

\begin{abstract}
Abstrak: Pertumbuhan ekonomi negara dapat tercermin dari bagaimana sektor properti dan real estate tumbuh. Properti dan real estate diyakini sebagai salah satu sektor terkemuka yang menunjukkan kesehatan ekonomi di suatu negara, karena sektor-sektor tersebut tumbuh seiring dengan pertumbuhan ekonomi. Properti dan real estate cenderung bersifat jangka panjang dan membutuhkan modal besar. Oleh karena itu, banyak perusahaan di sektor ini mendaftarkan saham mereka di pasar modal, untuk menciptakan potensi investasi yang baik bagi investor. Namun, karena sifatnya yang jangka panjang, properti dan real estate memiliki risiko di mana investor harus menghindarinya. Penelitian ini bertujuan untuk menentukan dua risiko utama pada properti dan real estate, pertumbuhan ekonomi dan ukuran serta nilai saham perusahaan dengan menggunakan model CAPM dan Fama-French, dan membandingkan model mana yang dapat mengidentifikasi pengembalian yang lebih baik untuk sektor properti dan real estate. Penelitian menunjukkan bahwa kondisi ekonomi secara signifikan mempengaruhi kelebihan return properti dan real estat Indonesia. Perusahaan dengan ukuran perusahaan besar dan rasio book-to-market yang rendah diketahui mendominasi sektor properti dan real estate. Secara keseluruhan, kedua model menunjukkan hasil yang sama dan konsisten, namun Fama-French Three Factor Model dipastikan lebih baik dalam mengidentifikasi kelebihan pengembalian sektor properti dan real estat Indonesia.
\end{abstract}

Kata kunci: CAPM, property and real estate, three factor model

\footnotetext{
${ }^{1}$ Corresponding author:

Email: afifbobby@gmail.com
} 


\section{INTRODUCTION}

A nation's economic growth could be reflected by stock market trading volume, one of which are on Property and Real Estate sector. Many consider property and real estate as leading indicator to a nation economic condition, including Indonesia. Indonesia is one of the countries that has become a property business which is wide open and still growing (Fakoano et al. 2018). Santoso and Budi (2005) stated that property and real estate often signaling economic fluctuation by analyzing firms performances. The better the firms performances, the better the economic conditions are. The property business generally characterized as long term investment with huge investment value and oftentimes providing a really good return on investment.

Property and real estate sectors require huge capital investment, due to requirement of land ownership and construction cost. Including the marketing effort which generally need substantial amount of time to perform, property and real estate also tend to require a very good cash flow capacity. Therefore, many of property and real estate firms chose to seek capital from stock market to fulfill their financial requirement. This creates an opportunities for investor to invest at property and real estate in the stock market. Jogiyanto (2010) states that returns are the results obtained from an investment.

The main motive for investors to invest are to gain return, either from dividend or capital gain (Tandelilin, 2001), and property and real estate are a good investment destination in recent years. However, risks will always be a factor investor must keep an eye for. Risks are commonly identified as gap between expected return and the actual return (Sharpe, 1970). Samsul (2006) categorized risk on two categories, Systematic Risks and Unsystematic Risks. Unsystematic risks are type of risks which generally affect only certain firms, such as financial capabilities, human resources capabilities, et cetera. Unsystematic risk commonly could be averted by diversifying portfolio. Systematic risk, however, are type of risks that affect all firms regardless their internal capabilities, such as inflation, fuel prices, and exchange rate. Systematic risks could not be prevented by diversification.

Risks on property and real estate could be caused by many factors, however long time investment characteristics and reliance to economic conditions are believed to be the main factors. In Indonesia, property and real estate are entering declining and stagnant phase in recent years, compared by its golden year during 2011 to 2014, as seen from weekly return performance on Figure 1.

As seen on Figure 1, in 2011 the average weekly return peaked at $1.042 \%$. In the following years, the average started to decline, moving to weekly average of $0.612 \%$ in 2012 and $0.555 \%$ in 2013 . The performance rebounded in 2014, performing at $0.644 \%$ and then sharply declining to $-0.149 \%$ and $-0.019 \%$ in 2015 and 2016 respectively. This decline in performance were caused by the decline in Indonesian general public purchasing power in recent years.

Investor requires information to guide their investment decision, both internal information such as financial statement and external information such as macro factors risk. According to Horne and Wachowich (1992), risk is defined as the variability between expected return and actual return. Without having the correct information, these variability will be greater than it should be.

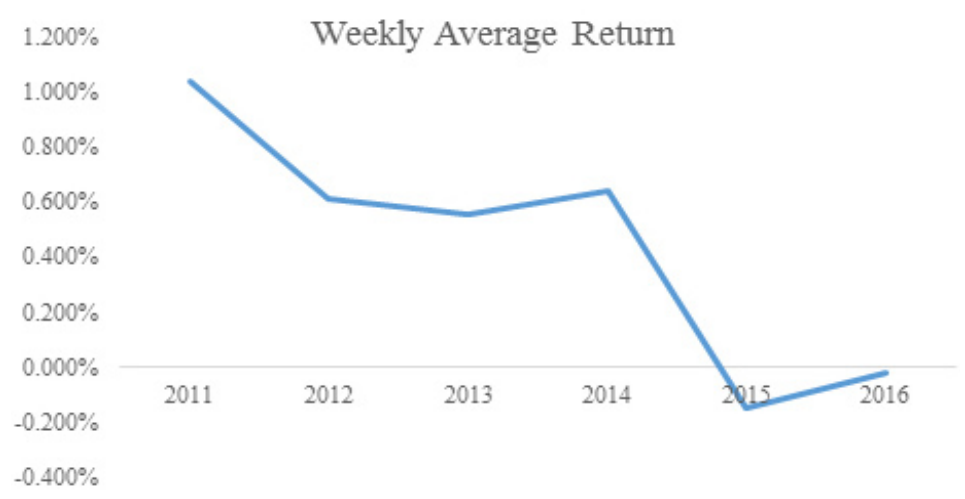

Figure 1. Property and real estate weekly average return 
There are many method that can be used to provide these information, such as technical analysis and fundamental analysis. This research focused on identifying macro factors, especially market information and firm strength among other variables. These variables were chosen to provide variables that could be commonly accessed by investors, so that the result could provide general informations for both amateur and veteran investors.

There are two methods that can be used to identify the variables, which are Capital Asset Pricing Model (CAPM) and Fama-French Three Factors Model (FFTFM). CAPM are often used to identify market risk (beta) on stock return, whereas FFTFM adds two more variables, Small Minus Big (SMB) and HML (High Minus Low) in addition to market risk (Bodie et al. 2005). CAPM method will be used to identify the degree of significance of market proxy to the excess return of Indonesian property and real estate sectors and FFTFM will be used to identify the degree of significance of the firms characteristics.

FFTFM were firstly proposed by Fama and French (1993) as an expansion of CAPM method. While CAPM only used market index as independet variable, FFTFM extended the variables with Firm Size and Book-toMarket (BTM) ratio. Banz (1981) viewed that firm capitalization significantly affeced its return. The higher firm capitalization, the higher the return will be. The same goes for BTM ratio. Rosenberg et al. (1985) found that firms with low BTM ratio yield better return than those with high BTM ratio. Low BTM ratio reflected high stock market value, and High BTM ratio reflected low stock market value.

CAPM model in general is a linear regression between firm excess return and market risk premium. Market risk premium is how market index return perform against risk free rate. Positive market risk premium shows that market index return is higher than risk free rate, therefore market index is a better investment than risk free rate (which also shows that economic condition are favorable), vice versa.

Many research utilize CAPM model and FFTFM model to explain the variance of macro factor to stock return. Oke (2013) found that CAPM were able to identify risk and its correlation to stock return in Nigeria stock market. Adiwiratama (2010) stated that firm size significantly affected the stock return. In property and real estate sector, Sudarsono and Sudiyatno (2016) utilized FFTFM model and found that firm size positive significantly affected stock return. Hardianto and Suherman (2009) stated that firm value shows significant effect to stock return.

CAPM and FFTFM are also often used to complement and compare each other. Hanif and Hidayat (2015) compared both model and found that FFTFM model slightly had better predicting power than CAPM. Similar result can be found on research by Panta et al. (2016) which also stated that FFTFM model have better predicting power. Even though FFTFM model are often regarded as the better prediction model, research by Jain (2013) showed that FFTFM was unable to give satisfactory result when explaining Indian Stock Market. This is likely due to too many unexplained variables affecting the stock return. Pasaribu and Bismark (2009) conducted a research on the formation of stock portfolios in Indonesia using the Fama and French models. The results showed a significant relationship between market, size, and book-to-market equity with the return of shares on the Indonesia Stock Exchange.

While CAPM and FFTFM are simple methods and both are considered as ineffective predictive models by many, especially compared to technical statics analysis, CAPM and FFTFM are still regarded as powerful tools to determine correlating variables. In case of property and real estate sector's long term nature, fundamental analysis are especially crucial. Therefore, by utilizing CAPM and FFTFM, hypotheses in this research arises as follow: Market risk premium are significantly affecting excess return; Firm size (SMB) are significantly affecting excess return; Firm value (HML) are significantly affecting excess return.

Yuningsih and Yudharuddin (2007) conducted a similar research to property and real estate sectors using FamaFrench Three Factors Model within period of 2002 to 2006 and found significancy of the variables to property and real estate sectors. This research, while conducted by utilizing the same method, also used another model as a comparison and conducted in a different economic condition, to reconfirm consistency of these variables for property and real estate sectors in a different frame of period.

Considering the vast scope of problems that must be solved in estimating returns, the researchers will limit the problem with the intention that the objectives of the discussion can be more directed and on target. The 
problem that the researchers discussed in this study is limited to the supporting factors found in the FamaFrench Three-Factor Model on the return of issuers in the property and real estate sector in the period 20112016. Therefore, the results of this study are to answer research question proposed as follow: Are CAPM and/ or FFTFM could identify general variables affecting excess return of Indonesian property and real estate sectors?, Which model are better to be used in term of predicting power and accuracy?.

\section{METHODS}

First variable used in this study is Indonesia economic condition proxied by Indonesia market index, Jakarta Stock Exchange, or stated in this research as market return. Dewi (2006) stated that market index are commonly used to represent economic condition, as market index are usually the fastest source reflecting economic situation. CAPM model, firstly proposed by Sharpe (1964) are designed to seek correlation and measure the effect of market index to expected return of a firm. CAPM core foundation lies on the belief that market index composed from many stocks from all sectors, therefore as a whole, market index will affect certain stock return in form of systematic risk, in this case are property and real estate sector.

Second variable are firm strength. This variable are added to complement economic variable, since economic by itself will provide vague information to investors. As capital intensive sectors, firm strength plays major role on profit creation. Firm strength comes from many source, such as financial strength, expertise, assets, and many more. However, firm strength could be represented by its size (firm size) and stock value (firm value).

Firm size will represent their financial, expertise, assets, and technological capabilities in general and stock value will represent their ability on profit making. Theoritically, big sized firms with high stock price value will provide better return than its counterpart. Therefore, by utilizing CAPM and FFTFM, hypotheses in this research arises as follow: 1) Market risk premium are significantly affecting excess return; 2) Firm size (SMB) are significantly affecting excess return; 3) Firm value (HML) are significantly affecting excess return.

This study analyzed 31 firms on property and real estate sector listed prior to January 1st 2011 as shown in Table 1. Weekly firm and market return data taken from Indonesia Stock Exchange database are used from 6 years period of 2011 to 2016. This study also assuming all firms receive same exposure to systematic risks, therefore will be using panel regression. Firm return and market return are firstly transformed into excess return and market risk premium respectively, by subtracting the return to risk free rate proxied by central bank interest rate. Then, firms are classified into respective size (big and small) and value (high BTM and low BTM).

Table 1. Property and real estate firm

\begin{tabular}{lclc}
\hline \multicolumn{1}{c}{ Firm Name } & *Abbreviation & \multicolumn{1}{c}{ Firm Name } & *Abbreviation \\
\hline Agung Podomoro Land & APLN & Perdana Gapura Prima & GPRA \\
Alam Sutera Reality & ASRI & Jaya Real Property & JRPT \\
Bekasi Asri Pemula & BAPA & Kawasan Industri Jababeka & KIJA \\
Bumi Citra Permai & BCIP & Eureka Prima Jakarta & LCGP \\
Bhuawanatala Indah Permai & BIPP & Lippo Cikarang & LPCK \\
Bukit Darmo Property & BKDP & Lippo Karawaci & LPKR \\
Sentul City & BKSL & Modernland Realty & MDLN \\
Bumi Serpong Damai & BSDE & Metropolitan Kentjana & MKPI \\
Cowell Development & COWL & Metro Realty & MTSM \\
Ciputra Development & CTRRA & Pudijati Prestige & PUDP \\
Duta Anggada Realty & DART & Pakuwon Jati & PWON \\
Firm Name & Abbr* & Firm Name & Abbr.* \\
Bakrieland Development & ELTY & Roda Vivatex & RDTX \\
Fortune Mate Indonesia & FMII & Pikko Land Development & RODA \\
Goa Makassar Tourism Development & GMTD & Suryamas Dutamakmur & SMDM \\
\hline
\end{tabular}

*Abbreviation used on Indonesian Stock Exchange 
Firms size are classified by comparing individual firm average market capitalization against whole firms average market capitalization as benchmark. If firm average market capitalization are higher than the benchmark, then it is classified as Big Size firm, otherwise Small size firm. Firm value are classified by measuring the BTM ratio against the benchmark. Firm with BTM ratio over $70 \%$ are classified as High BTM value, firm with BTM ratio below $30 \%$ are classified as Low BTM value, and firm with BTM ratio in between $30 \%$ to $70 \%$ are classified as Medium BTM value. SizeValue classification resulted in 1 Big-High (BH) class, 3 Big-Medium (BM) class, 6 Big-Low (BL) class, 10 Small-High (SH) class, 8 Small-Medium (SM) Class, and 3 Small-Low (SL) class. Firm classification matrix sorted by the stock abbreviation is depicted on Table 2.

The next step is to regress the data into CAPM model and FFTFM model. Excess return and market risk premium are immediately regressed for CAPM model. Meanwhile, SMB variable and HML variable must first be calculated prior to FFTFM regression.

SMB variable is calculated by subtracting Small Size firm (SH, SM, SL) return average respectively to Big Size firm (BH, BM, BL) return average respectively, then divided by three. SMB variable could be expressed as follow:

Table 2. Firm size and value classification matrix

\begin{tabular}{|c|c|c|c|}
\hline \multirow[t]{2}{*}{ FIRM SIZE } & \multicolumn{3}{|c|}{ FIRM VALUE } \\
\hline & HIGH (abbr*) & MEDIUM (abbr*) & LOW (abbr*) \\
\hline $\mathrm{BIG}$ & BKSL & $\begin{array}{c}\text { CTRA } \\
\text { KIJA } \\
\text { RODA }\end{array}$ & $\begin{array}{c}\text { BSDE } \\
\text { JRPT } \\
\text { LPCK } \\
\text { LPKR } \\
\text { MKPI } \\
\text { SMRA }\end{array}$ \\
\hline SMALL & $\begin{array}{c}\text { BAPA } \\
\text { BIPP } \\
\text { BKDP } \\
\text { DART } \\
\text { ELTY } \\
\text { MDLN } \\
\text { MTSM } \\
\text { PUDP } \\
\text { RBMS } \\
\text { SMDM }\end{array}$ & $\begin{array}{c}\text { APLN } \\
\text { COWL } \\
\text { DILD } \\
\text { FMII } \\
\text { GMTD } \\
\text { GPRA } \\
\text { LCGP } \\
\text { PWON }\end{array}$ & $\begin{array}{c}\text { ASRI } \\
\text { BCIP } \\
\text { RDTX }\end{array}$ \\
\hline
\end{tabular}

\footnotetext{
*Abbreviation used on Indonesian Stock Exchange
}

$$
\mathrm{SMB}=((\mathrm{SH}+\mathrm{SM}+\mathrm{SL})-(\mathrm{BH}+\mathrm{BM}+\mathrm{BL})) / 3
$$

HML variable is calculated by subtracting return average of High BTM firm ( $\mathrm{SH}, \mathrm{BH})$ respectively to Low BTM firm (SL, BL) return average respectively, then divided by two. HML variable could be expressed as follow:

$$
\mathrm{HML}=((\mathrm{SH}+\mathrm{BH})-(\mathrm{SL}+\mathrm{BL})) / 2
$$

Then, the variable of SMB, HML, and Market Risk Premium are regressed by using panel regression to the FFTFM function as follow:

$$
(\mathrm{Ri}-\mathrm{Rf})=\mathrm{Rf}+\beta \mathrm{i}(\mathrm{Rm}-\mathrm{Rf})+\gamma \mathrm{i}(\mathrm{SMB})+\delta \mathrm{i}(\mathrm{HML})
$$

Description: Ri (return of firm -i); Rf (risk free rate); $\alpha$ (intercept); $\beta \mathrm{i}$ (coefficient of market risk premium); $\mathrm{Rm}$ (market index return); $\gamma \mathrm{i}$ (coefficient of SMB); SMB (Small Minus Big); $\Delta \mathrm{i}$ (coefficient of HML); HML (High Minus Low).

As for CAPM model, the variable used are only market risk premium to stock excess return, which are regressed by linear function as follow:

$$
(\mathrm{Ri}-\mathrm{Rf})=\mathrm{Rf}+\beta \mathrm{i}(\mathrm{Rm}-\mathrm{Rf})
$$

Description: Ri (return of firm -i); Rf (risk free); $\beta \mathrm{i}$ (firm sensitivity to market risk); Rm (market index return). 
After regressing both models, the final steps are to find out which of the two models could provide better predicting power. This will be done by comparing Adjusted R-Squared value, Root Mean Squared Error (RMSE) and Mean Absolute Error (MAE) from both models. Adjusted R-Squared provide information on how good the variables of each model on explaining variance of excess returns, the higher the better (Draper and Smith 1998). Meanwhile RMSE and MAE will measure the error of each model on predicting excess return, the lower the better (Hyndman and Koehler, 2005).

To summarize the methodology, this research observed the correlation and impact of both macro and micro factors represented by market risk premium, firm size (SMB) and firm value (HML) on the excess return of property and real estate sector. The research utilized CAPM model and Fama-French Three Factor Model under panel data regression analysis to test the hypotheses. Then both model are compared to figure out which model are the best to analyze variance of the variables to property and real estate excess return. Theoritical framework of the research could be seen on Figure 2.

\section{RESULTS}

The first model analyzed to identify the effect of economic condition to property and real estate sector's excess return were CAPM model. Regression result of CAPM model is shown on Table 3. As seen from the result, market risk premium which represent Indonesia economic condition have significant positive correlation to property and real estate excess return with coefficient value of 0.7990 (rounded up). The results shows a linear correlation between two variable, which means that whenever market risk premium increase by 1 (one) percent, then property and real estate sector excess return will increase by $0.7990 \%$, and vice versa.

As stated on the background, improvement on general economic condition will result in increase on public purchasing power, which subsequently increase housing demand and ultimately resulting on property and real estate stock price. Thus, increase or decrease on market risk premium as a proxy of economic condition will directly increase or decrease excess return on property and real estate. Similar result were also produced by Nasuha et al. (2013). Nasuha conducted similar research on property and real estate in different time frame and consistently found that market risk premium also had significant positive correlation to property and real estate sectors.

The same results are also proven by FFTFM model regression. FFTFM regression results shows that market risk premium, among other two variables, have positive significant correlation to excess return of property and real estate sectors. FFTFM model regression results is seen on Table 4.

Market risk premium have coefficient value of 0.7111 , lower than the result from CAPM model. However, both show consistent results, economic condition is in a linear correlation to property and real estate excess return

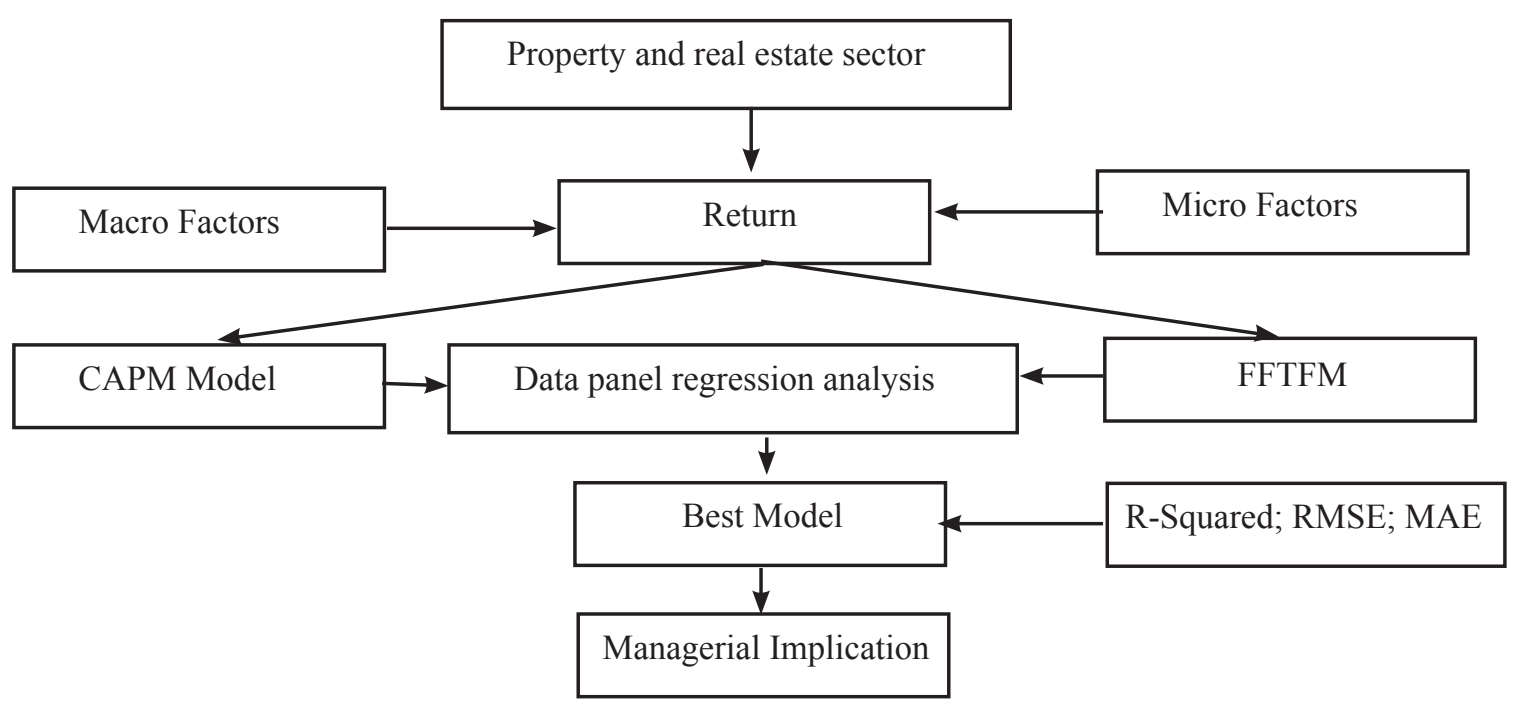

Figure 2. Research framework 
Table 3. CAPM model regression

\begin{tabular}{|c|c|c|c|c|}
\hline Variable & Coefficient & Std. Error & t-Statistic & Prob. \\
\hline Market Risk Premium & 0.798957 & 0.025247 & 31.64611 & 0.0000 \\
\hline $\mathrm{C}$ & 0.002261 & 0.000572 & 3.954249 & 0.0001 \\
\hline \multicolumn{5}{|c|}{ Weighted Statistics } \\
\hline R-squared & 0.093846 & Mean dependent var & & 0.003171 \\
\hline Adjusted R-squared & 0.093752 & S.D. dependent var & & 0.071215 \\
\hline S.E. of regression & 0.067806 & Sum squared resid & & 44.45869 \\
\hline F-statistic & 1001.476 & Durbin-Watson stat & & 2.005261 \\
\hline $\operatorname{Prob}($ F-statistic) & 0.000000 & & & \\
\hline
\end{tabular}

Table 4. FFTFM model regression result

\begin{tabular}{|c|c|c|c|c|}
\hline Variable & Coefficient & Std. Error & t-Statistic & Prob. \\
\hline Market Risk Premium & 0.711121 & 0.027921 & 25.70477 & 0.0000 \\
\hline SMB & -0.170450 & 0.023262 & -7.219583 & 0.0000 \\
\hline HML & -0.045266 & 0.019020 & -2.239196 & 0.0000 \\
\hline $\mathrm{C}$ & 0.002045 & 0.000724 & -3.117937 & 0.0018 \\
\hline \multicolumn{5}{|c|}{ Weighted Statistics } \\
\hline R-squared & 0.102504 & Mean dependent var & & -0.014677 \\
\hline Adjusted R-squared & 0.102225 & S.D. dependent var & & 0.071644 \\
\hline S.E. of regression & 0.067714 & Sum squared resid & & 44.32902 \\
\hline F-statistic & 368.0625 & Durbin-Watson stat & & 2.009620 \\
\hline Prob(F-statistic) & 0.000000 & & & \\
\hline
\end{tabular}

SMB have significant and negative correlation to excess return with coefficient value of -0.1705 . This means that whenever SMB increase by 1 (one) percent, excess return of property and real estate will decrease by $0.1705 \%$. Same negative and significant correlation are also shown by HML variable with coefficient value of -0.0453 . This means that whenever HML increase by 1 (one) percent, then excess return of property and real estate will decrease by $0.0453 \%$, and vice versa.

Negative value in both SMB and HML shows that property and real estate sector performance are dominated by Big size firms and Low BTM (high market price) firms. When Big size firms and Low BTM firms outperform their Small size and High BTM counterpart, negative SMB and HML value will be produced. In practice, the results prove a strong logical sense. As previously stated, property and real estate sectors are capital intensive. Therefore, big size firm will naturally provide the required capital capabilities, and Low BTM firms have high market price which reflect their ability to utilize the capital, thus creating the possibilities on producing higher return.
All three general variables are in accordance to the research hypotheses. However, the coefficient value of market risk premium, SMB, and HML are all below 1. These value show that excess return of property and real estate are insensitive to all three variables, which means that the excess return fluctuation will never be higher than the variables fluctuation. This also makes a very good sense in practical term.

In good economic condition, increase on housing demand will likely come from secondary housing investment from higher income citizen. Meanwhile, when Indonesian economic condition is slowing down, such as in recent years occurances, the demand on housing will not be sharply decline, as middle to low income citizen will still in demand on primary housing.

The same goes to big size firms and low BTM firms. Even though firms in either or both class have proven capital capabilities and capital utilization, property and real estate have a long term investment characteristic. Almost every property and real estate projects are a multi-year projects. Therefore, whenever firms announce their property and real estate plan, which 
could jump-start their stock price and excess return, the increase will not be as much since long time projects tend to have unexpected risks along the way and the increase on stock price and excess return occurs from increase in public confidence.

Both CAPM and FFTFM model are able to provide answer to which general systematic risk are affecting property and real estate excess return. The big questions is which of these two models are better on predicting the excess return. Fauzy (1998) stated that there are no fixed statistical procedure to determine the best regression model. However, adjusted R-Squared, Root Mean Squared Error (RMSE), and Mean Absoulte Error (MAE) could be used to distinguished the models. Adjusted R-Squared, RMSE and MAE comparison value is shown on Table 5 .

Table 5. Adjusted R-Squared, RMSE, dan MAE Comparison

\begin{tabular}{lccc}
\hline Model & $\begin{array}{c}\text { Adjusted } \\
\text { R-Squared }\end{array}$ & RMSE & MAE \\
\hline CAPM & $9.3752 \%$ & 0.067825 & 0.03826 \\
FFTFM & $10.2225 \%$ & 0.067865 & 0.03822 \\
\hline
\end{tabular}

Comparison of Adjusted R-Squared, RMSE and MAE from CAPM and FFTFM shows that FFTFM has better predicting ability, since the adjusted R-Squared and MAE are better than CAMP model. However, RMSE and MAE difference between the two models are not significant at all and the difference in Adjusted R-Squared shows that FFTFM have more variables explaining the variance of excess return. This means that both model could potentially be used as investment guideline, depending on what information investor has. Similar result is observed on research by Yolita and Fauzie (2014), who found that both firm size and firm value affected stock return. Firm with big size and low value tend to have high market price, thus higher return. Meanwhile, small size firm and high value firm tend to have lower market price, thus providing lower return.

\section{Managerial Implications}

This study aims to find out general systematic risks variables affecting property and real estate excess return by using CAPM and FFTFM models. Results show that both models could satisfy the goals. Market risk premium as proxy of Indonesian economic condition,
SMB as proxy of firm size, and HML as proxy of firm value, significantly affected property and real estate excess return as explained by CAPM and FFTFM model regression.

CAPM model shows a significant result showing that market risk premium, which represented Indonesian economics conditions positively affects property and real estate sectors. This implied that the growth of property and real estate sectors will follow the growth of Indonesian economies. Investors are advised to pay attention to Indonesian general economic condition, and closely monitor the various policies dynamics. Any positive sentiment to economics condition, specifically sentiment that lead to increase in personal income, would potentially increase the excess return to property and real estate sector. Thus allowing investors to generate better return in the investment.

Firm size was also proven to have significant effect to excess return. While the magnitude of the effect was less than market risk premium, the implication was crystal clear. Indonesian property and real estate sector are dominated by big size firms. Whenever big size firm's return increased, potential excess return to investor also increased. Therefore, investors are advised to prioritize their investments on the big sized firms. Aside from the potential excess return, big sized firms also provide more confidence to investors due to their above-average capital.

As for firm value, while result shows significant effect to excess return, the magnitude of effect are the lowest among all variables. Even though it's implied that property and real estate sectors are also dominated by high market price firms, the effect of excess return increase are only $0.05 \%$ for each percent of firm's increase in return. Therefore, while investor are still advised to invest at high-priced firms due to the lower risk sentiment, investors could invest to lower priced firms they favor, while bearing in mind not to invest at high BTM ratio firms due to high risk they possess.

Theoritically, this research shows that in ideal condition, investors are recommended to invest when the economic conditions are at positive to very positive sentiment and allocate their investment fund to big sized firms with high market price. However, discretion from investors are highly advised, as these ideal condition cannot be predicted. 


\section{CONCLUSIONS AND RECOMMENDATIONS}

\section{Conclusions}

Result shows that CAPM model have positive significant effect to excess return with loading factor of 0.7989 . On FFTFM model, the result shows that all three variables of market risk premium, SMB, and HML significantly affected excess return with loading factors of $0.7111,-0.1705$, and -0.0453 respectively. Both models consistently showed the same result for market risk premium and both model are proven to show significant results for each variable, either simultaneously.

CAPM resulted in R-Squared value of $9.375 \%$ while FFTFM showed higher R-Squared value at $10.222 \%$. CAPM had lower Root Mean Squared Error than FFTFM, however FFTFM had lower Mean Absolute Error value than CAPM model. At the end, both CAPM and FFTFM do not have significant difference in terms of value. In conclusion, FFTFM is the better model to explain the variance of variables to excess return.

\section{Recommendations}

Statistically, the model on this research are not recommended to be used as exact value prediction, instead as general information on which factors to consider before investment. Even though both models could provide significant answer to the latter, R-squared value are unable to produce satisfying number. This is due to high data volatility since the data used in this research are weekly return data. CAPM dan FFTFM models are found unsuitable to predict excess return within the time frame.

\section{REFERENCES}

Adiwiratama J. 2012. Pengaruh Informasi Laba, Arus Kas dan Size Perusahaan terhadap return Saham (Studi empiris pada perusahaan manufaktur yang terdaftar di BEI). JINAH (Jurnal Ilmiah Akuntansi dan Humanika). 2(1).

Banz RW. 1981. The relationship between return and market value of common stocks. Journal of Financial Economics 9(1): 3-18.

Bodie Z. Kane A, Marcus AJ. 2005. Investment. Terjemahan Zuliani D dan Budi Wibowo. Jakarta: Salemba Empat.
Dewi A. 2006. Analisis penggunaan capital asset pricing model dan arbitrage pricing theory dalam memprediksi return saham kelompok Jakarta islamic index [tesis]. Bogor: Institut Pertanian Bogor.

Draper NR, Smith H. 1998. Applied Regression Analysis. Wiley-Interscience.

Fakoano V, Achsani NA, Ahmad TN. 2018. Financial performance of the property company using zmijewski method. Jurnal Aplikasi Manajemen dan Bisnis 4(3): 341-353.

Fama E, French KR. 1993. Common risk factors in the return on stock and bonds. Journal of Finance Economics 33: 3-56.

Fauzy A. 1998. Memilih persamaan regresi terbaik. Arena Almamater 46:25-31

Hanif SI, Hidayat RR .2015. The Comparison Between Fama-french Three Factors Model (Ff3fm) and Capital Asset Pricing Model (Capm) as Investing Decision on Efficient Share (Study of Lq45 Listed in Indonesian Stock Exchange Periods of July 2010-June 2014). Jurnal Administrasi Bisnis 28(1): 193-203.

Hardianto D, Suherman S. 2009. Pengujian famafrench three-factor model di Indonesia. Jurnal keuangan dan Perbankan 13(2): 198-208.

Horne JCV, Wachowicz JM. 1992. Fundamentals of Financial Management. Prentice Hall: Englewood Cliffs, N.J

Hyndman R, Koehler A. 2005. Another look at measures of forecast accuracy.

Jain S. 2013. Fama-French Three Factor Model in Indian Stock Market'. The Current global trends 2(1): 7-13.

Jogiyanto. 2010. Analisis dan Desain Sistem Informasi, Edisi IV, Andi Offset, Yogyakarta

Nasuha R, Dzulkirom M, dan Zahroh ZA. 2013. Analisis metode capital asset pricing model dalam upaya pengambilan keputusan terhadap investasi saham (Studi pada saham-saham perusahaan sektor properti dan real estate di Bursa Efek Indonesia (BEI) Periode 2010-2012 [tesis]. Malang: Universitas Brawijaya.

Oke BO. 2013. Capital Asset Pricing Model (CAPM): evidence from Nigeria. Research Journal of Finance and Accounting 4(9): 17-26.

Panta SB, Phuyal N, Sharma R, Vora G. 2016. The cross-section of stock returns: an application of fama-french approach to Nepal. Modern Economy 7(02): 223.

Pasaribu RBF, Bismark F. 2009. Model fama dan 
french sebagai pembentukan portfolio saham di Indonesia. Jurnal Akuntansi dan Bisnis 9(1): $1-12$.

Rosenberg B, Reid K, Lanstein R. 1985. Persuasive evidence of market inefficiency. The Journal of Portfolio Management 11(3): 9-16.

Samsul M. 2006. Pasar Modal \& Manajemen Portofolio. Jakarta: Erlangga

Santoso, Budi. 2005. Prospek Kredit Properti. Economic Review Journal 199.

Sharpe WF. 1964. Capital asset prices: A theory of market equilibrium under conditions of risk. The journal of finance 19(3): 425-442.

Sharpe W.1970. Portfolio Theory and Capital Markets. McGraw-Hill Trade.
Sudarsono B, Sudiyatno B. 2016. Faktor-faktor yang Mempengaruhi Return Saham pada Perusahaan Property dan Real Estate yang Terdaftar pada Bursa Efek Indonesia tahun 2009-2014. Jurnal Bisnis dan Ekonomi 23(1).

Tandelilin E. 2001. Analisis Investasi dan Manajemen Portofolio. Jogjakarta:BPFE Jogjakarta.

Yolita, Fauzie S. 2014. Analisis stock returns perusahaan perbankan pada Jakarta composite index menggunakan fama-french three-factor model Vol 2, No 11.

Yuningsih I, Yudaruddin R. 2007. Pengaruh model tiga faktor terhadap return saham. Jurnal Akuntabilitas 7(1): 79-84. 